\title{
TUNNEL EVALUATION IN CROCKER FORMATION BY GEOLOGICAL STRENGTH INDEX (GSI) SYSTEM: A CASE STUDY
}

\author{
Lee Kiun You, Ismail Abd Rahim* \\ Faculty of Science and Natural Resources, Universiti Malaysia Sabah \\ *Corresponding Author E-mail: arismail@ums.edu.my
}

This is an open access article distributed under the Creative Commons Attribution License, which permits unrestricted use, distribution, and reproduction in any medium, provided the original work is properly cited.

\section{ARTICLE DETAILS}

\section{Article History:}

Received 26 June 2018 Accepted 2 July 2018 Available online 1 August 2018

\section{ABSTRACT}

This study was conducted to determine the value of Geological Strength Index (GSI), to predict rock mass properties very unfavourable discontinuities combination and tunnel support pressure for rock bolts or shotcrete and to determine the suitability of GSI for a tunnel in Crocker Formation. Engineering geological mapping and discontinuity survey was done along the tunnel face as well as rock sampling. GSI values and the disturbance factor were obtained from field observation on the tunnel face. Point load and dry density test was conducted to determine the Uniaxial Compressive Strength (UCS) and unit weight, respectively. The rock mass properties, kinematic analysis and limit equilibrium analysis was used to determine the factor of safety (F.O.S) and pressure to stabilise the tunnel. The rock mass was characterised by $94.88 \mathrm{MPa}$ UCS, $0.024 \mathrm{MN} / \mathrm{m} 3$ unit weight, widely space and high persistency. The GSI value is 50 with 0.8 disturbance factor. The cohesion, friction angle and tensile strength are $3.671 \mathrm{MPa}, 25.20^{\circ}$ and $0.056 \mathrm{MPa}$ respectively. The friction angle was reduced by $5^{\circ}$ due to lower shear strength of bedding plane. There are eight possibilities of discontinuities combinations on tunnel crown that have F.O.S lower than 2 and combination of joints 2,4 and 6 has the maximum wedge volume of $28.37 \mathrm{~m} 3$. The maximum support pressure of rock bolts or shotcrete for F.O.S of 2 at the tunnel crown is 0.04 MN. The high F.O.S value may have been due to the overestimation of friction angle and cohesion of discontinuity plane. Then, this study shows that GSI system is unsuitable for the tunnel in study area which behave as anisotropic and structurally controls rock mass, but if needed, the values of rock mass properties, discontinuities combination and support pressure can be used for tunnel design.

\section{KEYWORDS}

Geological Strength Index (GSI), tunnel, Crocker Formation, limit equilibrium analysis.

\section{INTRODUCTION}

This study was conducted along a tunnel in Tenom, Sabah (Figure 1) as shown in Photo 1. The study area is underlain by the Crocker Formation of Late Eocene to Late Early Miocene ages and consists of tectonically disturbed thick amalgamated sandstone with thin shale layers (Photo 2) [1]. The objectives of this study are to determine the value of Geological Strength Index (GSI), to predict the rock mass properties, very unfavourable discontinuities combination, tunnel support pressure for rock bolts or shotcrete and to determine the suitability of GSI system for the tunnel in study area.
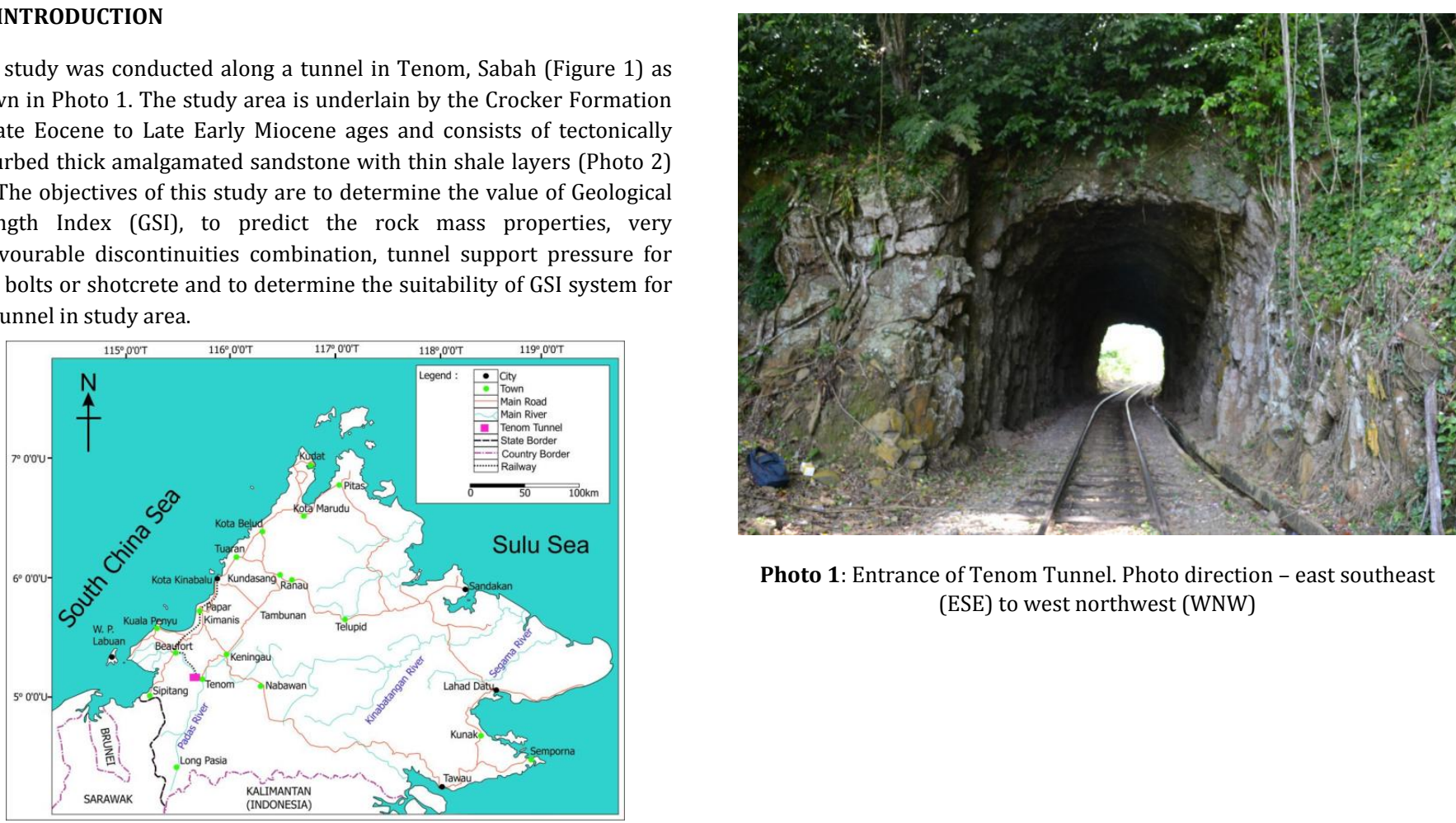

Photo 1: Entrance of Tenom Tunnel. Photo direction - east southeast (ESE) to west northwest (WNW)

Figure 1: Location of Tenom Tunnel 


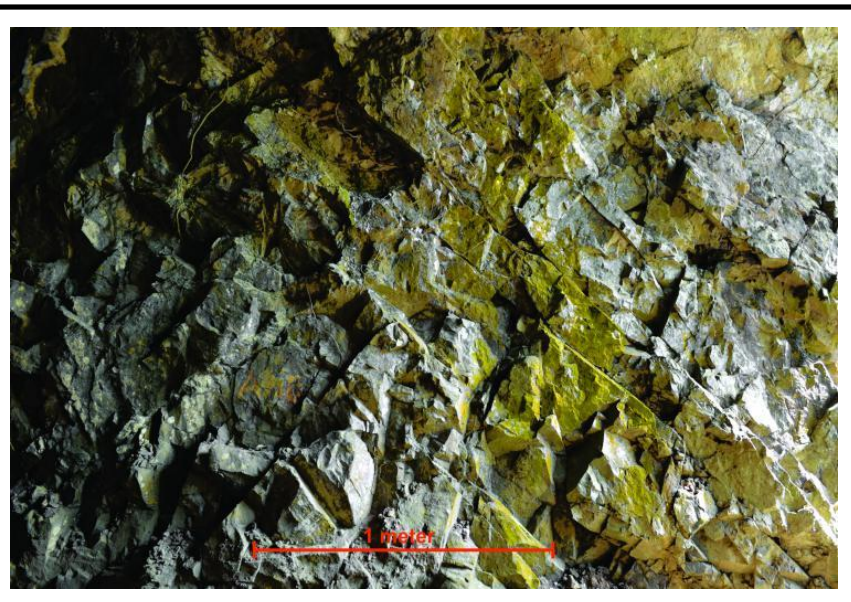

Photo 2: Amalgamated thick sandstone unit of Crocker Formation

Geological Strength Index (GSI) was introduced as an extension from Hoek-Brown criterion [2]. The index and its use for the Hoek-Brown failure criterion was further developed but it was still for hard rock system which generally equivalent to RMR [3-6]. While Evert Hoek and Paul Marinos were dealing with incredibly difficult materials encountered in tunnelling in Greece, they developed the GSI system for poor quality rock mass [7]. Although GSI system is only suitable for homogenous rock masses, it was applied in heterogeneous rock masses such as Flysch, until it was revised by Marinos [8,9].

GSI has been applied continuously in various major tunnel excavations around the world especially in heterogeneous rock masses such as flysch. One of the major applications of this system was done during the tunnel excavation for the Egnatia Highway in Northern Greece [10]. Another major application was done for the Chenani-Nashri Tunnel which is the longest road tunnel in India [11].

Study on the application of GSI for the tunnel in Crocker Formation has never been attempted thus this study has been conducted to determine the GSI value, to predict rock mass properties, very unfavourable discontinuities combination and tunnel support pressure for rock bolts or shotcrete and to determine the suitability of GSI for the tunnel in the study area.

\section{METHODOLOGY}

Lithological mapping, surface mapping and discontinuity survey were conducted to obtain quantitative description of discontinuities as well as rock sampling [12]. A researcher has been proposed to be using GSI charts for Crocker formation based on the surface condition together with the structure and composition of the tunnel face $[9,13,14]$. The disturbance factor of 0.8 was obtained by field observation on the tunnel face [15]. Laboratory study was done to determine the Uniaxial Compressive
Rock mass properties of the tunnel were determined using RocLab software where the input parameters are UCS of intact rock, GSI value, disturbance factor, and Hoek-Brown material constant [20]. RocLab uses the Hoek-Brown and Mohr-Coulomb criteria to empirically estimate the rock mass properties (cohesion, friction angle and tensile strength) based on the given parameters [15]. Result of rock mass properties were then used as input parameters into Unwedge software to determine the very unfavourable discontinuities combinations [21]. Wedge failure is the potential mode of failure based on kinematic analysis and limit equilibrium analysis. Unwedge software is based on the Block Theory [22]. Support pressure required for tunnel support by using rock bolts or shotcrete was calculated based on design factor of safety of 2 which is sufficient to avoid failure caused by the vibrations from passing train [8].

\section{RESULTS AND DISCUSSION}

The GSI value from field observation are 50 after being reduced from 55 as suggested by a researcher because the tunnel consists of thick amalgamated sandstone with thin shale layers instead of thick amalgamated sandstone with thin siltstone layers (Figure 2 and Photo 3) [23]. This value was obtained by identifying the surface condition and the type of the tunnel wall [14]. Based on the study, the surface condition of the tunnel wall is good with structure and composition of type III. The tunnel geometry and discontinuity orientation were shown in Table 1. Table 2 shows the result of laboratory testing, parameters and derived rock mass properties from related schemes and software. The disturbance factor was chosen as 0.8 because blasting and hammering were used in the excavation method [15]. Friction angle was reduced by $5^{\circ}$ due to shear strength of bedding plane.

The result of Unwedge software was presented in Table 3. There are eight out of the twenty possible discontinuities combinations on tunnel crown that have F.O.S lower than 2.0 with a maximum wedge volume of $28.37 \mathrm{~m}^{3}$ formed from combinations of joint 2, 4 and 6 (Figure 3). The wedges were formed by the combination of at least 3 discontinuities such as bedding and joint planes. The F.O.S value for crown wedges was nil because the wedge was practically hanging without support and might have failed immediately after excavation previously. The wedge blocks at the crown might have failed over the years and caused the shape of the crown to change from its initial shape. To achieve F.O.S of 2, rock bolts or shotcrete can be installed on the tunnel crown with maximum support pressure of $0.04 \mathrm{MN}$.

The high values of F.O.S for left and right wall might have been because the overestimation of friction angle and cohesion for individual discontinuity plane. Based on the result, rock mass properties obtained from GSI system should not be applied for individual discontinuity plane due to the rock mass properties do not represent individual discontinuity plane but the rock mass as the whole.

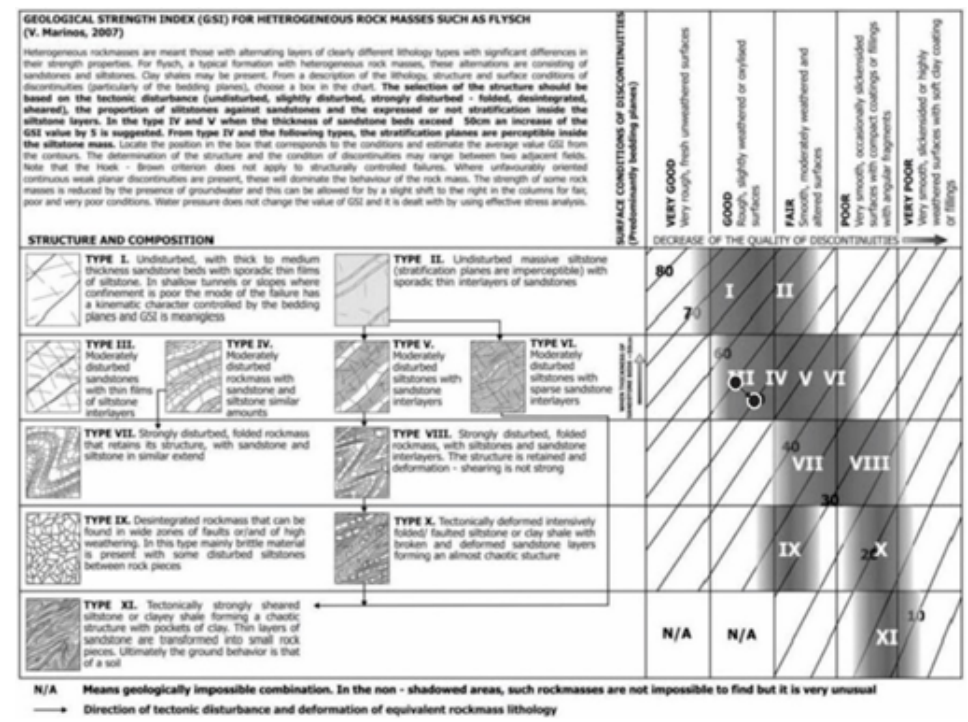

Figure 2: GSI chart and value for rock mass (black dot) [9] 


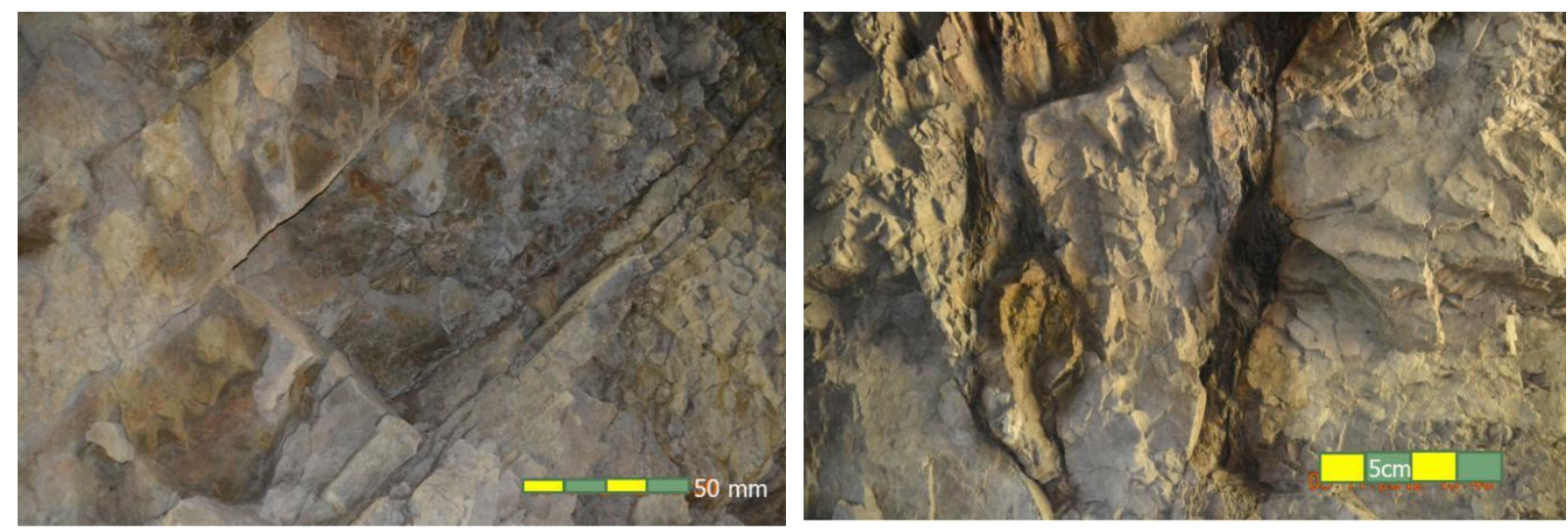

Photo 3: Amalgamated thick sandstone unit of Crocker Formation

Table 1: Tunnel geometry and discontinuity orientation

\begin{tabular}{|l|l|l|l|}
\hline Tunnel & Values & Discontinuity & Strike/Dip \\
\hline Length & $42.69 \mathrm{~m}$ & Joint 1, J1 & $30 / 60$ \\
\hline Width & $4.4 \mathrm{~m}$ & Joint 2, J2 & $185 / 55$ \\
\hline Height & $4.6 \mathrm{~m}$ & Joint 3, J3 & $215 / 70$ \\
\hline Right wall & $87^{\circ}$ & Joint 4, J4 & $87 / 42$ \\
\hline Left wall & $87^{\circ}$ & Joint 5, J5 & $2 / 24$ \\
\hline \multirow{2}{*}{} & \multirow{2}{*}{ Joint 6, J6 } & $277 / 86$ \\
\cline { 2 - 4 } &
\end{tabular}

Table 2: Parameters and rock mass properties

\begin{tabular}{|l|l|}
\hline Parameters / Properties & Values \\
\hline GSI & 50 \\
\hline Disturbance factor & 0.8 \\
\hline Unit Weight $\left(\mathrm{MN} / \mathrm{m}^{3}\right)$ & 0.024 \\
\hline Hoek-Brown material constant $\left(\mathrm{m}_{\mathrm{i}}\right)$ & 10 \\
\hline UCS $(\mathrm{MPa})$ & 94.88 \\
\hline Cohesion $(\mathrm{MPa})$ & 3.67 \\
\hline Friction angle for bedding $\left(^{\circ}\right)$ & 20.2 \\
\hline Friction angle for joint $\left(^{\circ}\right)$ & 25.2 \\
\hline Tensile strength $(\mathrm{MPa})$ & 0.056 \\
\hline
\end{tabular}

Table 3: Predicted discontinuities combinations which contain F.O.S below 2 including maximum support pressure needed and maximum wedge volume

\begin{tabular}{|c|c|c|c|c|}
\hline Combination & $\begin{array}{l}\text { Wedges on tunnel } \\
\text { section }\end{array}$ & F.0.S & Max. support pressure (MN) & Max. wedge volume $\left(\mathrm{m}^{3}\right)$ \\
\hline \multirow{4}{*}{$\mathrm{J} 1, \mathrm{~J} 2, \mathrm{~J} 6$} & Floor & Stable & 0.00 & 2.071 \\
\hline & Left & 1183.134 & 0.00 & 0.227 \\
\hline & Right & 3024.801 & 0.00 & 0.227 \\
\hline & Crown & 0.000 & 0.02 & 2.071 \\
\hline \multirow{4}{*}{$\mathrm{J} 1, \mathrm{~J} 2, \mathrm{~J} 3$} & Floor & Stable & 0.00 & 0.092 \\
\hline & Left & 6780.508 & 0.00 & 1.944 \\
\hline & Right & 1196.101 & 0.00 & 1.944 \\
\hline & Crown & 0.000 & 0.01 & 0.092 \\
\hline \multirow{4}{*}{$\mathrm{J} 1, \mathrm{~J} 2, \mathrm{~J} 5$} & Floor & Stable & 0.00 & 0.011 \\
\hline & Left & 812.480 & 0.00 & 18.362 \\
\hline & Right & 1231.028 & 0.00 & 18.362 \\
\hline & Crown & 0.000 & 0.00 & 0.011 \\
\hline \multirow{4}{*}{$\mathrm{J} 1, \mathrm{~J} 3, \mathrm{~J} 4$} & Floor & Stable & 0.00 & 0.125 \\
\hline & Left & 2874.700 & 0.00 & 13.102 \\
\hline & Right & 452.463 & 0.00 & 13.102 \\
\hline & Crown & 0.000 & 0.01 & 0.125 \\
\hline \multirow{4}{*}{$\mathrm{J} 2, \mathrm{~J} 4, \mathrm{~J} 5$} & Floor & Stable & 0.00 & 0.013 \\
\hline & Left & 12264.928 & 0.00 & 13.469 \\
\hline & Right & 371.609 & 0.00 & 13.469 \\
\hline & Crown & 0.000 & 0.00 & 0.013 \\
\hline \multirow{4}{*}{$\mathrm{J} 2, \mathrm{~J} 4, \mathrm{~J} 6$} & Floor & Stable & 0.00 & 28.370 \\
\hline & Left & 574.165 & 0.00 & 0.297 \\
\hline & Right & 3024.801 & 0.00 & 0.297 \\
\hline & Crown & 0.000 & 0.04 & 28.370 \\
\hline \multirow{4}{*}{$\mathrm{J} 3, \mathrm{~J} 4, \mathrm{~J} 5$} & Floor & Stable & 0.00 & 1.288 \\
\hline & Left & 1105.018 & 0.00 & 11.379 \\
\hline & Right & 371.609 & 0.00 & 11.379 \\
\hline & Crown & 0.000 & 0.01 & 1.288 \\
\hline \multirow{4}{*}{$\mathrm{J} 3, \mathrm{~J} 4, \mathrm{~J} 6$} & Floor & Stable & 0.00 & 24.068 \\
\hline & Left & 544.096 & 0.00 & 0.625 \\
\hline & Right & 2049.625 & 0.00 & 0.625 \\
\hline & Crown & 0.000 & 0.04 & 24.068 \\
\hline
\end{tabular}


In this study, GSI of class III and IV are characterized as a purely anisotropic and anisotropic rock masses, respectively [23]. And, it is representing structurally controls cut/ slopes faces. GSI is also suitable for isotropic rock cut/ slope faces or rock mass controls only[9]. But, occurrences of wedge failures by the combination of discontinuities shows that the rock mass in the study area are anisotropic and structurally controls rather than structurally controlled by rock mass controls.

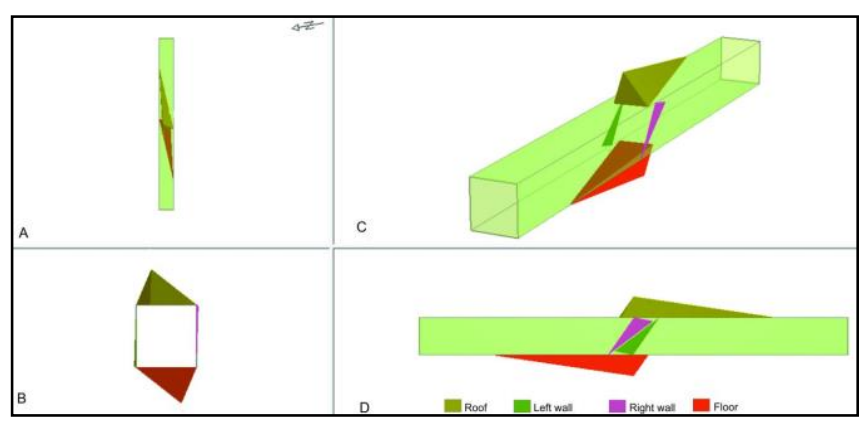

Figure 3: Blocks that can be formed from combination of J2J4J6 in four views.

A - Top view; B - Front view; C - 3D view; D - Side view.

\section{CONCLUSION}

It can be concluded that the GSI value for Crocker Formation for this case study is 55 , cohesion, friction angles and tensile strength are $3.67 \mathrm{MPa}$, $25.2^{\circ}$ and $0.056 \mathrm{MPa}$, respectively, very unfavourable discontinuities combination is $\mathrm{J} 2 \mathrm{~J} 4 \mathrm{~J} 6$, the support pressure for rock bolts and shotcrete are $0.04 \mathrm{MN}$ and GSI system is not suitable for the tunnel in study area, but the values of rock mass properties, discontinuities combination and support pressure can be used for tunnel design if needed.

\section{REFERENCES}

[1] Jasin, B., Tahir, S., Tating, F. F. 1991. Late Eocene planktonic foraminifera from the Crocker Formation, Pun Batu, Sabah. Warta Geologi, 174, 187-191.

[2] Hoek, E., Wood, D., Shah, S. 1992. A modified Hoek-Brown criterion for jointed rock masses. Proceeding Rock Characterization, Symposium International Society of Rock Mechanics: Eurock '92. (ed. J.A. Hudson). pp 209-214.

[3] Hoek, E. 1994. Strength of rock and rock masses. International Society of Rock Mechanics News Journal, 2 (2), 4-16.

[4] Hoek, E., Kaiser, P.K., Bawden, W.F. 1995. Support of Underground Excavations in Hard Rock. Rotterdam, Balkema.

[5] Hoek, E., Brown, E.T. 1997. Practical estimates of rock mass strength. International Journal Rock Mechanics, Mining Sciences \& Geomechanics Abstract, 34 (8), 1165.

[6] Bieniawski, Z.T. 1973. Engineering Classification of Jointed Rock Masses. Transaction of the South African Institution of Civil Engineering, 15 (12), 353-343.

[7] Marinos, P., Hoek, E. 2000a. GSI - A geologically friendly tool for rock mass strength estimation. Proceeding GeoEng2000 Conference. Melbourne.

[8] Marinos, P., Hoek, E. 2000b. From The Geological to the Rock Mass Model: Driving the Egnatia Highway through difficult geological conditions, Northern Greece. 10th International Conference of Italian National Council of Geologists: The fragile territory, Research and application on Hydrogeological disarray in the world, forecastingprevention-mitigation. Rome. pp 325-334.

[9] Marinos, V. 2007. Geotechnical classification and engineering geological behaviour of weak and complex rock masses in tunnelling. Doctoral thesis. School of Civil Engineering, Geotechnical Engineering Department, National Technical University of Athens (NTUA). Athens.
[10] Marinos, P., Hoek, E., Kazilis, N., Agistalis, G., Marinos, V. 2005. The tunnels of Egnatia highway. Design and construction in a variety of rock masses under difficult geological conditions. Proceedings of Geoline, CD.

[11] Palomba, M., Russo, G., Amadini, F., Carrieri, G., Jain, A.R. 2013. Chenani-Nashri Tunnel, the longest road tunnel in India: a challenging case for design-optimization during construction. Proceeding World Tunnel Congress 2013, Geneva. pp 965-97.

[12] ISRM. 1978. Suggested method for quantitative description of discontinuities in rock masses. International Journal of Rock Mechanics, Mining Sciences and Geomechanics Abstracts, 15, 319-368.

[13] You, L.K. 2016. Application of the GSI system for slope stability studies of the Crocker Formation in Kota Kinabalu area, Sabah. MSc Thesis, Universiti Malaysia Sabah, Kota Kinabalu (Unpublished).

[14] Bieniawski, Z.T. 1989. Engineering Rock Mass Classifications. Wiley, New York, 248.

[15] Hoek, E., Caranza-Torres, C.T., Corcum, B. 2002. Hoek-Brown failure criterion 2002 edition. In: Bawden HRW, Curran J, Telsenicki M (eds) Proceedings of the NARMS-TAC 2002. Mining Innovation and Technology, Toronto. pp 267-273.

[16] ISRM. 1985. Suggested method for determining point load strength. International Journal of Rock Mechanics, Mining Sciences and Geomechanics Abstracts, 22, 51-60.

[17] ISRM. 1977. SM for determining water content, porosity, density, absorption and related properties and swelling and slake-durability index properties. International Society of Rock Mechanics Suggested Method. pp 92-94.

[18] Marinos, V., Fortsakis, P., Prountzopoulos, G. 2011. Estimation of geotechnical properties and classification of geotechnical behaviour in tunnelling for flysch rock masses. Proceeding of the $15^{\text {th }}$ European Conference on Soil Mechanics And Geotechnical Engineering, Part 1, pp 435-440. Athens.

[19] Marinos, V. 2014. Tunnel behaviour and support associated with rock masses of flysch. Journal of Rock Mechanics and Geotechnical Engineering, 6, pp 227-239.

[20] Rocscience Inc. 2013. ROCLAB Ver. 1.0 Software for calculating HoekBrown rock mass strength. Toronto, Ontario, www.rocscience.com

[21] Rocscience Inc. 2004. UNWEDGE Ver. 3.0 Underground wedge stability analysis. Toronto, Ontario, www.rocscience.com

[22] Goodman, R.E., Shi, G. 1985. Block Theory and Its Application to Rock Engineering. Prentice-Hall Inc, Englewood Cliffs, New Jersey.

[23] Marinos, P. 2014. Personal communication.

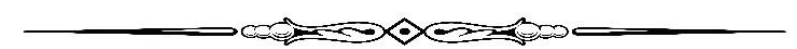

